\title{
Analisis Kepuasan Pengguna Aplikasi Traveloka Menggunakan Metode Technology Acceptance Model (TAM) Dan End-User Computing Satisfaction (EUCS)
}

Analysis Of User Satisfaction Of The Traveloka Application Using The Technology Acceptance Model (TAM) And The End-User Computing Satisfaction (EUCS) Method

\author{
Dien Novita ${ }^{1}$, Fareza Helena ${ }^{2}$ \\ ${ }^{1,2}$ Program Studi Sistem Informasi, STMIK Global Informatika MDP \\ E-mail: ${ }^{1}$ dien@mdp.ac.id, ${ }^{2}$ fareza.helena @mhs.mdp.ac.id
}

\begin{abstract}
Abstrak
Saat ini e-commerce dibutuhkan untuk memenuhi kebutuhan masyarakat dalam era digital. Salah satu e-commerce yang digunakan untuk memenuhi kebutuhan perjalanan masyarakat adalah Traveloka yang saat ini menjadi platform yang populer dengan seringnya dikunjungi oleh masyarakat. Dikarenakan banyaknya pengguna yang melakukan perjalanan dengan menggunakan aplikasi Traveloka maka dilakukanlah penelitian untuk mengukur apakah pengguna aplikasi Traveloka merasa puas saat menggunakan aplikasi tersebut. Model yang akan digunakan untuk mengukur kepuasan pengguna adalah Metode Technology Acceptance Model (TAM) dan Metode End-User Computing Satisfaction (EUCS). Proses pengumpulan data dilakukan dengan penyebaran kuisioner kepada 100 responden. Berdasarkan hasil analisis yang telah dilakukan menggunakan metode TAM semua hipotesis diterima yaitu perceived ease of use berpengaruh terhadap perceived usefulness, perceived ease of use berpengaruh terhadap attitude toward using, attitude toward using berpengaruh terhadap behavioral intention dan behavioral intention berpengaruh terhadap actual usage. Hal ini menunjukkan bahwa pengguna puas dengan aplikasi Traveloka. Sedangkan metode EUCS, dari 5 hipotesis, hanya 3 hipotesis yang berpengaruh terhadap kepuasan pengguna yaitu variabel content, format, dan ease of use. Hal ini menunjukkan dari 10 pengujian hipotesis, $80 \%$ disimpulkan bahwa Traveloka memenuhi kepuasan pengguna dan sisanya $20 \%$ pihak pengelola harus memperhatikan faktor tampilan dan respon time aplikasi.
\end{abstract}

Kata kunci: Traveloka, kepuasan, pengguna, TAM, EUCS

\begin{abstract}
Currently, e-commerce is needed to meet the needs of society in the digital era. One of the e-commerce sites that are used to meet the travel needs of the community is Traveloka, which is currently a popular platform with frequent visits by the public. Due to the large number of users who travel using the Traveloka application, research is conducted to measure whether Traveloka application users are satisfied when using the application. The models that will be used to measure user satisfaction are the Technology Acceptance Model (TAM) Method and the End-User Computing Satisfaction (EUCS) Method. The data collection process was carried out by distributing questionnaires to 100 respondents. Based on the results of the analysis that has been carried out using the TAM method, all hypotheses are accepted, namely, that perceived ease of use has an effect on perceived usefulness, perceived ease of use affects attitude toward using, attitude toward using has an effect on behavioral intention and behavioral intention has an effect on actual usage. This shows that users are satisfied with the Traveloka application. While the EUCS method, out of 5 hypotheses, only 3 hypotheses affect user satisfaction, namely the variable content, format, and ease of use. This shows that out of 10 hypothesis testing, 80\% concluded that Traveloka fulfilled user satisfaction, and the remaining $20 \%$ the manager had to pay attention to the display factor and application response time.
\end{abstract}


Keywords: Traveloka, satisfaction, users, TAM, EUCS

\section{PENDAHULUAN}

E-commerce didefinisikan sebagai transaksi komersial yang melibatkan pertukaran nilai yang dilakukan melalui atau menggunakan tekonologi digital antara individu [1]. Media ecommerce melibatkan penggunaan internet, world wide web, dan aplikasi atau browser pada perangkat selular atau mobile untuk bertransaksi bisnis. Platform mobile adalah pengembangan terbaru dalam infrastruktur Internet dari berbagai perangkat mobile seperti smartphone dan tablet melalui jaringan nirkabel (wifi) atau layanan telepon seluler. Pada awal berkembangnya $e$ commerce, satu-satunya media digital adalah web browser, namun saat ini media yang lebih banyak digunakan adalah melalui aplikasi mobile [1].

Saat ini e-commerce dibutuhkan untuk memenuhi kebutuhan masyarakat dalam era digital, Salah satu e-commerce yang digunakan untuk memenuhi kebutuhan perjalanan masyarakat adalah Traveloka yang menjadi platform yang populer dengan seringnya dikunjungi oleh masyarakat. Perkembangan teknologi memungkinkan para pelaku bisnis di Indonesia mengembangkan kegiatan bisnisnya untuk tetap menjaga hubungan baik dengan para pelanggan [2].

Pada tahun 2019, Traveloka menjadi aplikasi pemesanan hotel dan tiket yang paling disukai kaum milenial. Survei yang diwakili oleh 1204 responden dari generasi milenial ini menunjukkan Traveloka sebagai aplikasi pemesanan tiket dan hotel terpopuler di mana konsumen menyatakan akan terus menggunakan aplikasi tersebut ke depannya. Hasil riset ini juga menunjukkan Traveloka telah digunakan oleh 79 persen responden, sebuah angka yang mendominasi aplikasi pemesanan hotel dan tiket lainnya seperti Tiket.com $(8,9 \%)$, Blibli.com $(5,6 \%)$, KAI Access $(3,2 \%)$, dan Airy $(2,4 \%)[3]$.

Hingga saat ini, dari penelitian [3] aplikasi Traveloka sudah diunduh lebih dari 40 juta kali sehingga menjadikan Traveloka sebagai aplikasi pemesanan perjalanan dan gaya hidup terpopuler di kawasan Asia Tenggara. Keberhasilan Traveloka dalam memperluas penawaran produk menjadi suatu keunggulan kompetitif di mana Traveloka dapat memperkuat persepsi brand serta jumlah pengguna. Untuk lebih meyakinkan kepuasan pengguna aplikasi Traveloka yang dominan di tahun 2019, maka penulis tertarik melakukan penelitian untuk mengukur apakah responden merasa puas menggunakan aplikasi tersebut.

Penelitian ini dilakukan untuk menganalisis kepuasan pengguna platform aplikasi mobile dan website traveloka. Model yang akan digunakan untuk mengukur kepuasan pengguna adalah Metode Technology Acceptance Model (TAM) dan Metode End-User Computing Satisfaction (EUCS). Teori Technology Acceptance Model (TAM) merupakan salah satu model yang dibangun untuk menganalisis dan memahami faktor $\square$ faktor yang mempengaruhi diterimanya penggunaan teknologi komputer. TAM merupakan model penelitian yang paling luas digunakan untuk meneliti adopsi teknologi informasi dalam literatur sistem informasi manajemen. TAM juga menjelaskan hubungan sebab akibat antara keyakinan dan perilaku, tujuan atau keperluan, serta penggunaan aktual dari pengguna suatu sistem informasi. Model ini menyediakan dasar teori untuk menelusuri faktor yang menjelaskan pemakaian software dan menghubungkannya dengan kinerja pemakai [4].

Peneliti menggunakan TAM dimana akan mengusulkan desain portal, organisasi resources, serta user abilities and skills sebagai variabel independen sedangkan variabel dependen yang juga merupakan variabel dasar dalam TAM terdiri dari perceived ease of use, perceived usefulnes, attitude toward using, behavioral intention dan actual usage [5].

End User Computing Satisfaction (EUCS) merupakan sebuah model untuk menghitung tingkat kepuasan pengguna akhir suatu sistem informasi. Pada model EUCS terdapat lima faktor yang dapat mempengaruhi kepuasan user terhadap penerapan suatu sistem informasi. Doll dan Torkzadeh menyatakan bahwa terdapat lima faktor yang perlu diperhatikan dalam mengembangkan sebuah sistem informasi adalah: isi (Content), ketepatan (Accuracy), bentuk 
(Format), kemudahan penggunaan (Ease of Use), dan ketepatan waktu (Timeliness) [6].

\section{METODE PENELITIAN}

\subsection{Tahapan Penelitian}

Tahapan penelitian menganalisis kepuasan pengguna aplikasi Traveloka menggunakan metode Technology Acceptance Model (TAM) dan End-User Computing Satisfaction (EUCS) seperti Gambar 1 berikut:

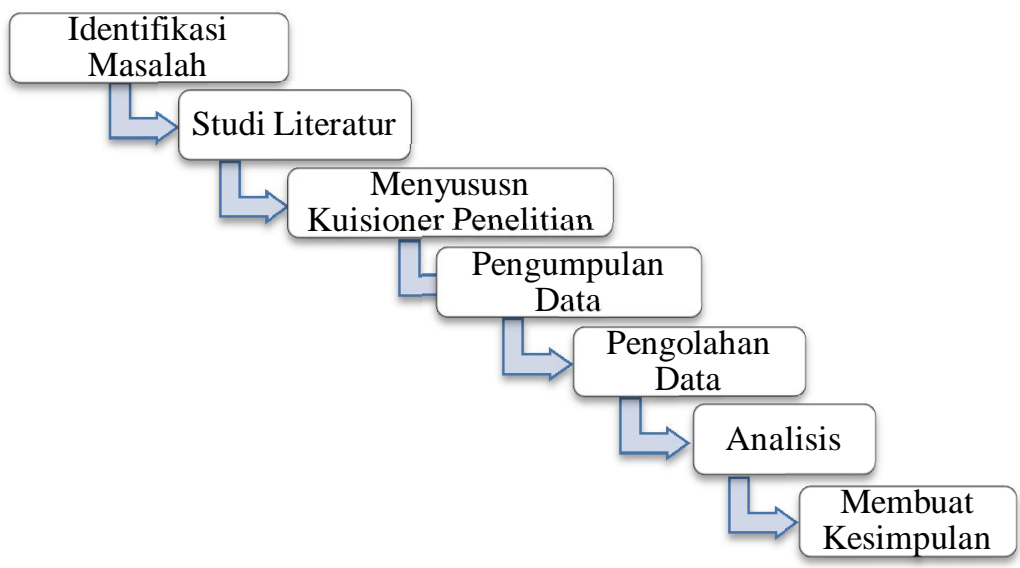

Gambar 1. Tahapan Penelitian

Pengumpulan data penelitian ini dilakukan melalui studi literatur dan kuisioner, yaitu:

a. Studi Literatur

Studi literatur merupakan penelitian yang dilakukan oleh peneliti dengan mengumpulkan sejumlah buku buku, majalah yang berkaitan dengan masalah dan tujuan penelitian. Teknik ini dilakukan dengan tujuan untuk mengungkapkan berbagai teori-teori yang relevan dengan permasalahan yang sedang dihadapi/diteliti sebagai bahan rujukan dalam pembahasan hasil penelitian [7].

b. Kuesioner

Kuesioner merupakan teknik pengumpulan data yang dilakukan dengan cara memberi seperangkat pertanyaan atau pernyataan tertulis kepada responden untuk dijawab. Kuesioner juga cocok dugunakan bila jumlah responden cukup besar dan tersebar di wilayah yang luas. Kuesioner dapat berupa pertanyaan/ pernyataan tertutup atau terbuka dapat diberikan kepada responden secara langsung atau dikirimkan melalui pos, atau internet [8]. 
Langkah awal penelitian yaitu melakukan observasi langsung ke lapangan atau tempat studi kasus untuk mengetahui permasalahan yang ada. Kemudian melakukan studi literatur untuk mencari referensi yang berhubungan dengan penelitian yang akan dilakukan [9]. Setelah itu mengidentifikasi jumlah populasi yang ada untuk mendapatkan jumlah sampel. Kemudian mulai membuat kuesioner dan disebarkan kepada pengguna aplikasi Traveloka dengan menyebarkan secara acak. Penulis dapat menggunakan data primer, yaitu data yang dikumpulkan dari respondennya langsung atau dari sumber pertama [10]. Penulis menyebarkan kuisioner menggunakan Google Form yang disebarkan ke pengguna aplikasi Traveloka sebanyak 100 responden. Setelah selesai menyebarkan kuesioner, maka data tersebut akan di analisis dengan melakukan pengujian persyaratan analisis, uji validitas, uji reliabilitas, analisis deskriptif, analisis regresi berganda dan uji hipotesis dengan melakukan uji t dan uji $\mathrm{F}$ pada variabel EUCS dan TAM menggunakan SPSS dan SmartPLS lalu dibuat kesimpulan.

\subsection{Populasi dan Sampel}

Populasi dalam penelitian ini adalah pengguna aplikasi Traveloka yang jumlahnya tidak diketahui dan dapat dikatakan dalam kategori tidak terhingga. Sampel adalah bagian dari jumlah dan karakteristik yang dimiliki oleh populasi. Bila populasi besar, dan peneliti tidak mungkin mempelajari semua yang ada pada populasi, misalnya karena keterbatasan dana, tenaga dan waktu, maka peneliti dapat menggunakan sampel yang diambil dari populasi itu. Apa yang dipelajari dari sampel itu, kesimpulannya akan dapat diberlakukan untuk populasi. Untuk itu sampel yang diambil dari populasi harus betul-betul representative atau mewakili.

\subsection{Penentuan Sampel}

Dalam menentukan jumlah sampel yang akan digunakan dalam penelitian ini, dihitung menggunakan rumus Paul Leedy [11]. Margin of error (moe) sebesar $10 \%$ dan tingkat keyakinan sebesar 95\% $(Z=1,96)$.

$$
\begin{aligned}
& n=\left(\frac{Z}{e}\right)^{2} p(1-p) \\
& n=\left(\frac{1,96}{0,05}\right)^{2} 0,5(1-0,05) \\
& n=96,04
\end{aligned}
$$

Tingkat kesalahan (e) yang dapat ditoleransi pada penelitian ini ditetapkan sebesar 0,05 atau 5\% dan tingkat keyakinan dalam penentuan sampel yang digunakan adalah $95 \%$ atau $\mathrm{z}=1,96$. Nilai tingkat keyakinan $95 \%$ atau $\mathrm{z}=1,96$ adalah tingkat keyakinan yang paling sering digunakan. Tingkat keyakinan $95 \%$ atau $\mathrm{Z}=1,96$ memberikan keseimbangan antara presisi dan reliabilitas. Berpedoman hasil perhitungan tersebut maka jumlah responden dibulatkan sebanyak 100 orang responden.

\subsection{Variabel Penelitian}

Berdasarkan studi literatur, diperoleh variabel dan indikator yang digunakan penelitian merujuk pada jurnal penelitian sebelumnya seperti pada Tabel 1 yaitu variabel dan indikator penelitian metode TAM.

Tabel 1. Variabel dan Indikator Penelitian Metode TAM

\begin{tabular}{|c|c|c|c|}
\hline Variabel & Kode & Indikator & Sumber \\
\hline \multirow{2}{*}{$\begin{array}{c}\text { Perceived } \\
\text { Usefulness (X1) }\end{array}$} & PU1 & peningkatan performa kinerja & {$[12]$} \\
\cline { 2 - 4 } & PU2 & bermanfaat & {$[13]$} \\
\cline { 2 - 4 } & PU3 & mempercepat pekerjaan & {$[14]$} \\
\hline
\end{tabular}




\begin{tabular}{|c|c|c|c|}
\hline \multirow{3}{*}{$\begin{array}{c}\text { Perceived Ease of } \\
\text { Use (X2) }\end{array}$} & PEOU1 & mudah digunakan & [12] \\
\hline & PEOU2 & membantu kemudahan mencapai tujuan & [13] \\
\hline & PEOU3 & mudah dipahami & [14] \\
\hline \multirow{3}{*}{$\begin{array}{l}\text { Attitude Toward } \\
\text { Using (X3) }\end{array}$} & AT1 & tidak membosankan & [12] \\
\hline & AT2 & menarik & [15] \\
\hline & AT3 & dapat digunakan dimana saja dan kapan saja & [16] \\
\hline \multirow{3}{*}{$\begin{array}{l}\text { Behavioral } \\
\text { Intention (X4) }\end{array}$} & BI1 & fitur yang membantu & \multirow{3}{*}[12]{} \\
\hline & $\mathrm{BI} 2$ & mencoba menggunakan aplikasi & \\
\hline & $\mathrm{BI} 3$ & berlanjut dimasa datang & \\
\hline \multirow{2}{*}{ Actual Usage (X5) } & AU1 & frekuensi penggunaan & \multirow{2}{*}{ [17] } \\
\hline & AU2 & durasi penggunaan & \\
\hline
\end{tabular}

Berdasarkan studi literatur, diperoleh juga variabel dan indikator yang digunakan penelitian merujuk pada jurnal penelitian sebelumnya seperti pada Tabel 2 yaitu variabel dan indikator penelitian metode EUCS.

Tabel 2. Variabel dan Indikator Penelitian Metode EUCS

\begin{tabular}{|c|c|c|c|}
\hline Variabel & Kode & Indikator & Sumber \\
\hline \multirow{3}{*}{ Content (X4) } & $\mathrm{C} 1$ & sesuai kebutuhan & \multirow{3}{*}{ [18] } \\
\hline & $\mathrm{C} 2$ & mudah dipahami & \\
\hline & $\mathrm{C} 3$ & informasi sangat jelas & \\
\hline \multirow{3}{*}{ Accuracy (X5) } & A1 & $\begin{array}{c}\text { menampilkan informasi produk secara benar } \\
\text { dan akurat }\end{array}$ & {$[18,19]$} \\
\hline & $\mathrm{A} 2$ & $\begin{array}{l}\text { fitur yang di klik selalu menampilkan halaman } \\
\text { yang sesuai }\end{array}$ & {$[18]$} \\
\hline & A3 & jarang terjadi error & [19] \\
\hline \multirow{4}{*}{ Timeliness (X6) } & $\mathrm{T} 1$ & $\begin{array}{l}\text { respons time dalam menampilkan beranda } \\
\text { cukup cepat }\end{array}$ & \multirow{4}{*}[19,20]{} \\
\hline & $\mathrm{T} 2$ & $\begin{array}{c}\text { menampilkan informasi produk terbaru secara } \\
\text { cepat }\end{array}$ & \\
\hline & $\mathrm{T} 3$ & $\begin{array}{l}\text { menampilkan deskripsi / informasi produk } \\
\text { secara up to date }\end{array}$ & \\
\hline & $\mathrm{T} 4$ & $\begin{array}{l}\text { cs memberikan tanggapan secara cepat } \\
\text { pengguna complaint mengenai produk }\end{array}$ & \\
\hline \multirow{3}{*}{ Format (X7) } & F1 & memiliki warna yang menarik & \multirow{3}{*}{ [18] } \\
\hline & F2 & layout yang memudahkan & \\
\hline & F3 & mudah dipahami & \\
\hline \multirow{3}{*}{ Ease of use (X8) } & E1 & mudah digunakan & \multirow{3}{*}[18,21]{} \\
\hline & E2 & mudah diakses & \\
\hline & E3 & user friendly & \\
\hline \multirow{3}{*}{ Satisfaction $(Y)$} & S1 & sesuai kebutuhan & \multirow{3}{*}[20]{} \\
\hline & S2 & dapat diandalkan dimana saja dan kapan saja & \\
\hline & S3 & $\begin{array}{l}\text { mempermudah dalam mencari produk yang } \\
\text { dibutuhkan }\end{array}$ & \\
\hline
\end{tabular}

\section{5 Hipotesis Penelitian}

Penelitian ini menggunakan desain kausal yang bertujuan untuk menganalisis hubungan antara satu variabel dengan variabel lainnya. Desain kausal digunakan untuk menganalisis secara empiris variabel-variabel yang berpengaruh terhadap kepuasan pengguna (user satisfaction), yakni variabel isi (content), ketepatan (accuracy), bentuk (format), kemudahan 
penggunaan (ease of use), dan ketepatan waktu (timeliness) berdasarkan Model End-User Computing Satisfaction yang dirumuskan oleh Doll \& Torkzadeh yang digunakan dalam penelitian [18]. Selain itu, untuk mengukur kepuasan user terhadap penerapan suatu sistem informasi dalam penelitian ini juga menggunakan model Technology Acceptance Model (TAM) yang memiliki 5 faktor yaitu: perceived ease of use, perceived usefulness, attitude toward using, behavioral intention, actual usage. Gambar 2 berikut adalah hipotesis penelitian berdasarkan model TAM.

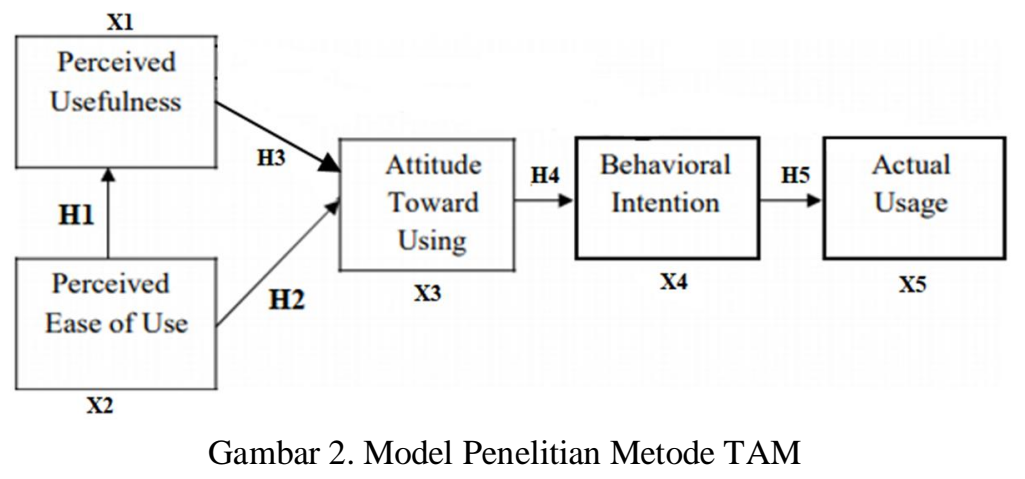

Gambar 3 berikut adalah hipotesis penelitian berdasarkan model EUCS yang memiliki 5 hipotesis.

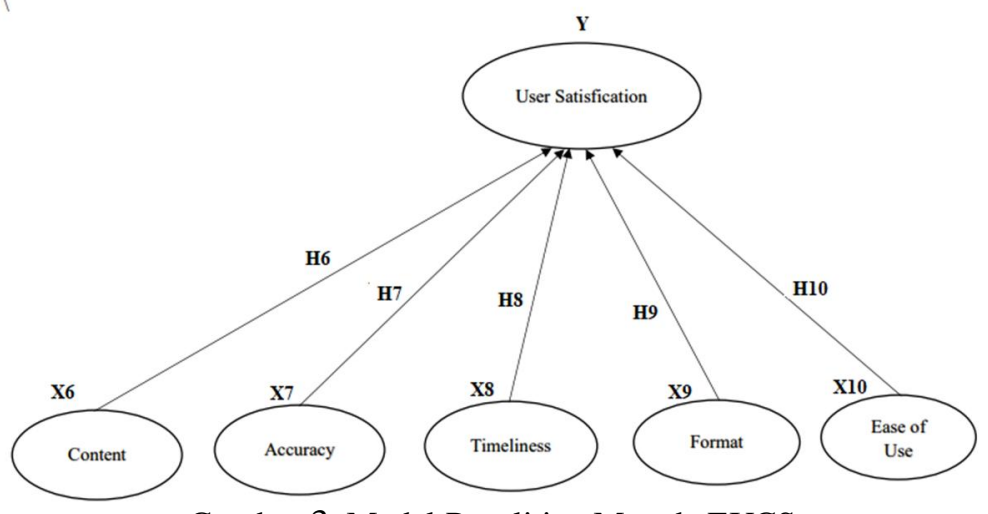

Gambar 3. Model Penelitian Metode EUCS

Sehingga, dirumuskan 10 hipotesis dalam penelitian ini, yaitu:

$\mathrm{H} 1$ : perceived ease of use berpengaruh terhadap perceived usefulness aplikasi Traveloka

$\mathrm{H} 2$ : perceived ease of use berpengaruh terhadap attitude toward using aplikasi Traveloka

$\mathrm{H} 3$ : perceived usefulness berpengaruh terhadap attitude toward using aplikasi Traveloka

$\mathrm{H} 4$ : attitude toward using berpengaruh terhadap behavioral intention aplikasi Traveloka

$\mathrm{H} 5$ : behavioral intention berpengaruh terhadap actual usage aplikasi Traveloka

H6 : Content berpengaruh terhadap terhadap user satisfication aplikasi Traveloka

H7 : Accuracy berpengaruh terhadap user satisfication aplikasi Traveloka

H8 : Timeliness berpengaruh terhadap user satisfication aplikasi Traveloka

H9 : Format berpengaruh terhadap user satisfication aplikasi Traveloka

H10 : Ease of Use berpengaruh terhadap user satisfication aplikasi Traveloka 


\section{HASIL DAN PEMBAHASAN}

\subsection{Profil Responden}

Data responden dikelompokkan berdasarkan jenis kelamin, usia, pekerjaan, intensitas akses aplikasi belanja online perhari, pernah bertransaksi, dan intensitas transaksi. Gambar 4 merupakan profil responden berdasarkan jenis kelamin.

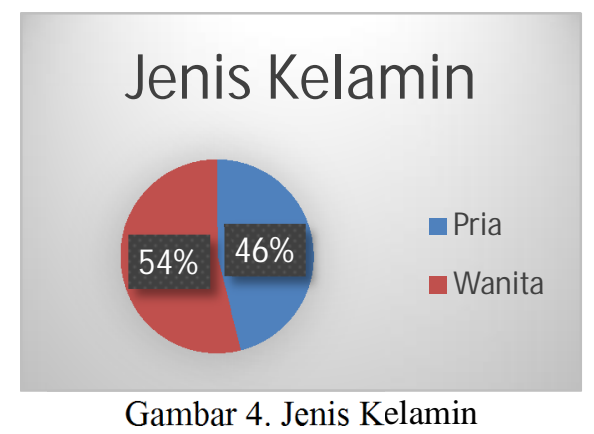

Dari gambar 3, menunjukkan bahwa dari 100 data responden yang digunakan dalam analisis ini, sebagian besar didominasi oleh responden berjenis kelamin wanita sebanyak 54 orang dengan persentase $54 \%$, sedangkan sisanya merupakan responden berjenis kelamin pria sebanyak 46 orang dengan persentase $46 \%$. Gambar 5 adalah data responden berdasarkan usia.

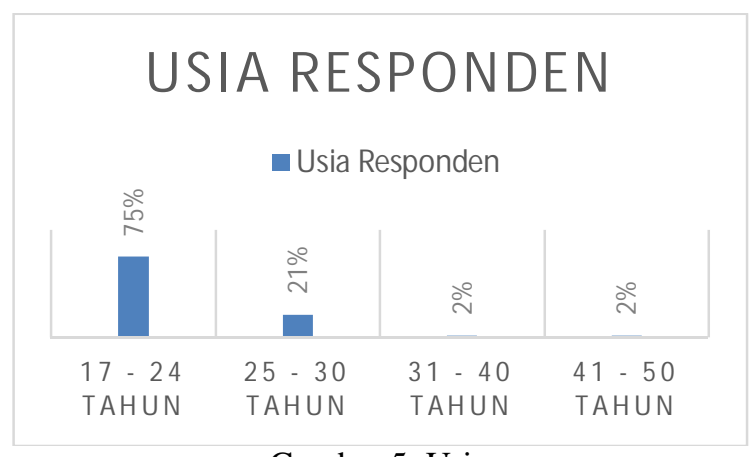

Gambar 5. Usia

Dari gambar 5, menunjukkan bahwa dari 100 data responden yang digunakan dalam analisis ini, sebagian besar didominasi oleh responden dengan rentang usia 17-24 tahun sebanyak 75 orang dengan persentase $75 \%$ selanjutnya diikuti dengan rentang usia responden 25-30 tahun sebanyak 21 orang dengan persentase 21\% kemudian 31-40 tahun sebanyak 2 orang dengan presentase $2 \%$ dan $41-50$ tahun sebanyak 2 orang dengan presentase $2 \%$.

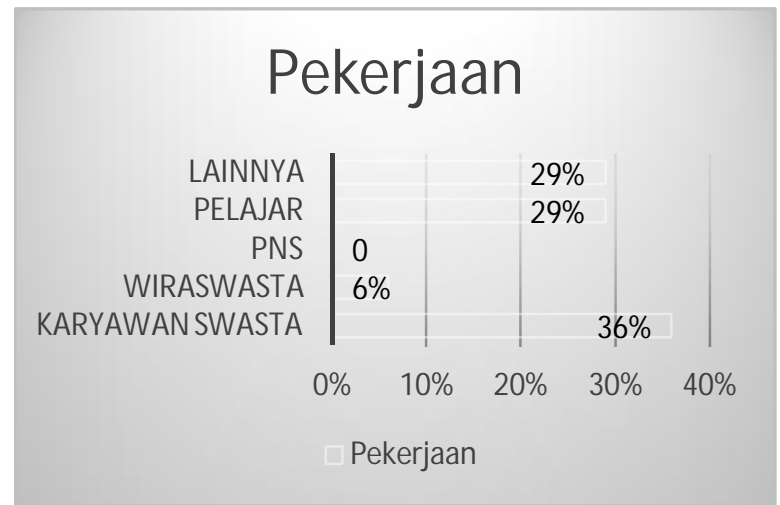

Gambar 6. Pekerjaan 
Dari gambar 6 dapat diketahui dapat diketahui bahwa pekerjaan responden paling banyak berasal dari pelajar dan lainnya sebanyak 29 orang dengan persentase $29 \%$ kemudian diikuti dengan karyawan swasta sebanyak 36 orang dengan presentase $36 \%$ selanjutnya wiraswasta sebanyak 6 orang dengan 6\%. Gambar 7 data responden berdasarkan intensitas responden mengakses aplikasi Traveloka perhari.

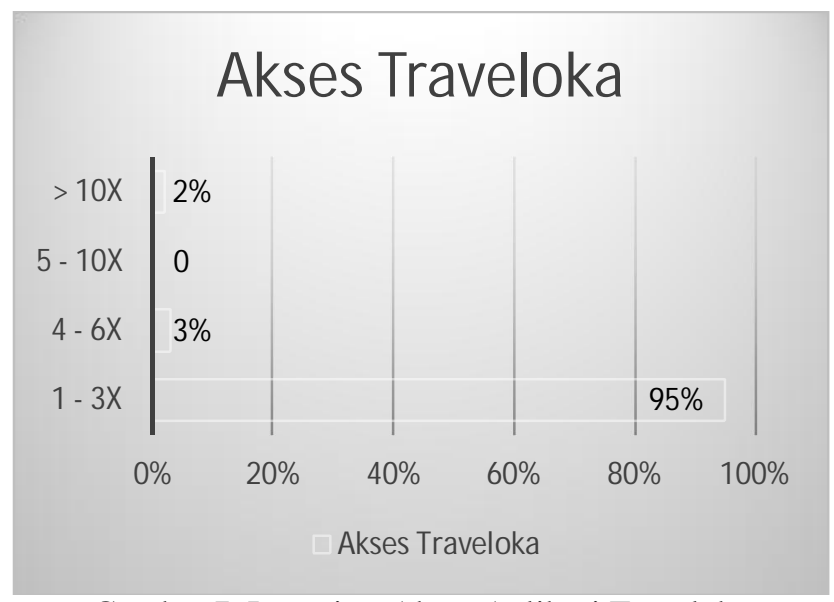

Gambar 7. Intensitas Akses Aplikasi Traveloka

Dari gambar 7 dapat diketahui bahwa data responden yang digunakan pada analisis ini menunjukan responden paling banyak yang mengakses traveloka sehari 1-3 kali berjumlah sebanyak 95 orang dengan persentase 95\%, kemudian diikuti dengan 4-6 kali dengan jumlah sebanyak 3 orang dengan presentase $3 \%$ dan $>10$ kali dengan jumlah sebanyak 2 orang dengan presentase $2 \%$.

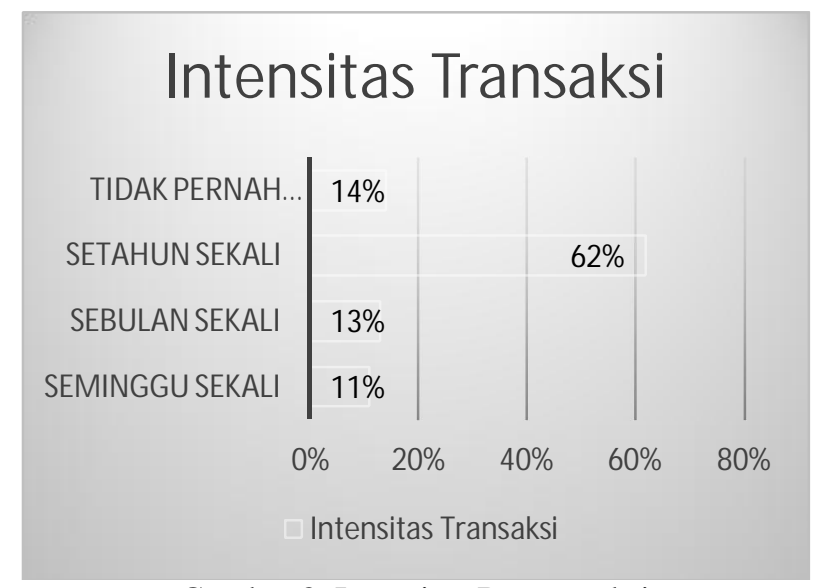

Gambar 8. Intensitas Bertransaksi

Dari gambar 8, dapat dilihat bahwa data responden yang digunakan pada analisis ini menunjukkan responden dengan intensitas bertransaksi sebanyak 1 tahun sekali berjumlah 62 orang dengan persentase $62 \%$, kemudian diikuti oleh 13 orang yang bertransaksi di Traveloka sebanyak 1 bulan sekali dengan presentase 13\%, kemudian diikuti oleh 11 orang yang bertransaksi di Traveloka sebanyak 1 minggu sekali dengan presentase $11 \%$ dan yang terakhir responden yang tidak pernah bertransaksi di Traveloka yaitu berjumlah 14 orang dengan presentase $14 \%$.

\section{2 Uji Validitas dan Reliabilitas}

Pengujian validitas dilakukan untuk memastikan seberapa baik instrumen digunakan untuk mengukur konsep yang seharusnya diukur, untuk menguji validitas konstruk yang 
dilakukan dengan cara mengorelasikan antara skor butir pertanyaan dengan skor totalnya [16]. Hasil dari perhitungan uji validitas ditunjukkan Tabel 3 .

Tabel 3. Uji Validitas Metode EUCS

\begin{tabular}{|c|c|c|c|c|}
\hline Indikator & rtabel & rhitung & Signifikan & Keterangan \\
\hline C1 & 0,195 & 0,902 & 0,000 & Valid \\
\hline C2 & 0,195 & 0,862 & 0,000 & Valid \\
\hline C3 & 0,195 & 0,859 & 0,000 & Valid \\
\hline A1 & 0,195 & 0,838 & 0,000 & Valid \\
\hline A2 & 0,195 & 0,796 & 0,000 & Valid \\
\hline A3 & 0,195 & 0,771 & 0,000 & Valid \\
\hline T1 & 0,195 & 0,816 & 0,000 & Valid \\
\hline T2 & 0,195 & 0,816 & 0,000 & Valid \\
\hline T3 & 0,195 & 0,812 & 0,000 & Valid \\
\hline T4 & 0,195 & 0,729 & 0,000 & Valid \\
\hline F1 & 0,195 & 0,868 & 0,000 & Valid \\
\hline F2 & 0,195 & 0,835 & 0,000 & Valid \\
\hline F3 & 0,195 & 0,848 & 0,000 & Valid \\
\hline E1 & 0,195 & 0,876 & 0,000 & Valid \\
\hline E2 & 0,195 & 0,839 & 0,000 & Valid \\
\hline
\end{tabular}

Dari hasil uji validitas variabel EUCS dengan menggunakan SPSS terhadap 100 responden dapat diambil kesimpulan bahwa semua item pernyataan tersebut memiliki nilai rhitung > rtabel dan nilai signifikansi p-value lebih kecil dari 0,05. Sehingga semua item pernyataan tersebut dapat digunakan dalam penelitian ini (valid).

Tabel 4. Uji Validitas Metode TAM

\begin{tabular}{|c|c|c|c|c|}
\hline Indikator & rtabel & rhitung & Signifikan & Keterangan \\
\hline PU1 & 0,195 & 0,765 & 0,000 & Valid \\
\hline PU2 & 0,195 & 0,750 & 0,000 & Valid \\
\hline PU3 & 0,195 & 0,704 & 0,000 & Valid \\
\hline PEOU1 & 0,195 & 0,873 & 0,000 & Valid \\
\hline PEOU2 & 0,195 & 0,851 & 0,000 & Valid \\
\hline PEOU3 & 0,195 & 0,838 & 0,000 & Valid \\
\hline AT1 & 0,195 & 0,782 & 0,000 & Valid \\
\hline AT2 & 0,195 & 0,848 & 0,000 & Valid \\
\hline AT3 & 0,195 & 0,743 & 0,000 & Valid \\
\hline B11 & 0,195 & 0,731 & 0,000 & Valid \\
\hline B12 & 0,195 & 0,851 & 0,000 & Valid \\
\hline B13 & 0,195 & 0,819 & 0,000 & Valid \\
\hline AU1 & 0,195 & 0,763 & 0,000 & Valid \\
\hline AU2 & 0,195 & 0,891 & 0,000 & Valid \\
\hline
\end{tabular}

Dari hasil uji validitas variabel TAM dengan menggunakan SPSS terhadap 100 responden dapat diambil kesimpulan bahwa semua item pernyataan tersebut memiliki nilai rhitung > rtabel dan nilai signifikansi p-value lebih kecil dari 0,05. Sehingga semua item pernyataan tersebut dapat digunakan dalam penelitian ini (valid).

Tabel 5. Uji Reliabilitas Metode EUCS 


\begin{tabular}{|c|c|c|c|}
\hline Variabel & Cronbach Alpha & Standar Reliabilitas & Keterangan \\
\hline Content & 0,845 & 0,7 & Reliabel \\
\hline Accuracy & 0,713 & 0,7 & Reliabel \\
\hline Timeliness & 0,798 & 0,7 & Reliabel \\
\hline Format & 0,802 & 0,7 & Reliabel \\
\hline Ease Of Use & 0,838 & 0,7 & Reliabel \\
\hline
\end{tabular}

Dari hasil uji reliabilitas semua variabel, diperoleh nilai-nilai Cronbach Alpha dari semua variabel penelitian ini menunjukkan lebih besar dari nilai 0,7 maka demikian jawabanjawaban responden dari variabel-variabel penelitian tersebut reliable, sehingga dapat digunakan untuk penelitian selanjutnya.

Tabel 6. Uji Reliabilitas Metode TAM

\begin{tabular}{|c|c|c|c|}
\hline Variabel & Cronbach Alpha & Standar Reliabilitas & Keterangan \\
\hline Perceived Usefulness & 0,586 & 0,7 & Reliabel \\
\hline Perceived Ease of Use & 0,814 & 0,7 & Reliabel \\
\hline Attitude Toward Using & 0,702 & 0,7 & Reliabel \\
\hline Behavioral Intention & 0,722 & 0,7 & Reliabel \\
\hline Actual Usage & 0,533 & 0,7 & Reliabel \\
\hline
\end{tabular}

Dari hasil uji reliabilitas semua variabel, diperoleh nilai-nilai Cronbach Alpha dari semua variabel penelitian ini menunjukkan lebih besar dari nilai 0,7 maka demikian jawabanjawaban responden dari variabel-variabel penelitian tersebut reliable, sehingga dapat digunakan untuk penelitian selanjutnya.

Dari hasil uji reliabilitas, diperoleh nilai-nilai Cronbach Alpha dari semua variabel penelitian ini menunjukkan nilainya lebih besar dari nilai 0,7 maka semua item pernyataan dapat dikatakan reliabel, sehingga dapat digunakan dalam penelitian.

\section{3 Analisis Regresi Linier Berganda}

Uji regresi berganda dalam penelitian ini dimaksudkan untuk melihat bagaimana pengaruh variabel independen terhadap dependen. Dengan menggunakan SPSS, regresi linier berganda didapatkan hasil Gambar 9 berikut:

\begin{tabular}{|c|c|c|c|c|c|c|c|c|}
\hline \multicolumn{9}{|c|}{ Coefficients $^{a}$} \\
\hline \multirow[b]{2}{*}{ Model } & & \multicolumn{2}{|c|}{ Unstandardized Coefficients } & \multirow{2}{*}{$\begin{array}{c}\text { Standardized } \\
\text { Coefficients } \\
\text { Beta }\end{array}$} & \multirow[b]{2}{*}{$t$} & \multirow[b]{2}{*}{ Sig. } & \multicolumn{2}{|c|}{ Collinearity Statistics } \\
\hline & & $B$ & Std. Error & & & & Tolerance & VIF \\
\hline \multirow[t]{6}{*}{1} & (Constant) & -.403 & .652 & & -.618 & .538 & & \\
\hline & Content & .228 & .087 & .226 & 2.615 & .010 & .362 & 2.763 \\
\hline & Accuracy & .122 & .079 & .124 & 1.554 & .124 & .428 & 2.334 \\
\hline & Timeliness & .076 & .067 & .094 & 1.132 & .261 & .390 & 2.561 \\
\hline & Format & .192 & .092 & .179 & 2.087 & .040 & .370 & 2.705 \\
\hline & Easeofuse & .404 & .087 & .378 & 4.614 & $<.001$ & .404 & 2.473 \\
\hline
\end{tabular}

a. Dependent Variable: Satisfaction

Gambar 9. Regresi Linier Berganda Metode EUCS

Berdasarkan hasil analisis gambar 9 diatas dapat dijelaskan melalui model regresi sebagai berikut:

$$
\mathrm{Y}=-0,403+0,228 \mathrm{X} 1+0,122 \mathrm{X} 2+0,076 \mathrm{X} 3+0,192 \mathrm{X} 4+0,404 \mathrm{X} 5
$$

Dari persamaan regresi tersebut dapat dijelaskan sebagai berikut:

1. Konstanta $=-0,403$. Artinya jika variabel content, accuracy, timeliness, format, ease of use 
dianggap sama dengan nol.

2. Koefisien content $=0,228$. Artinya jika variabel content mengalami kenaikan sebesar 1 satuan sedangkan variabel lain dianggap konstan, maka variabel dependen yaitu Kepuasan pengguna akan mengalami kenaikan sebesar 0,228.

3. Koefisien accuracy $=0,122$. Artinya jika variabel accuracy mengalami kenaikan sebesar 1 satuan sedangkan variabel lain dianggap konstan, maka variabel dependen yaitu Kepuasan pengguna akan mengalami kenaikan sebesar 0,122

4. Koefisien timeliness $=0,076$. Artinya jika variabel timeliness mengalami kenaikan sebesar 1 satuan sedangkan variabel lain dianggap konstan, maka variabel dependen yaitu Kepuasan pengguna akan mengalami kenaikan sebesar 0,076.

5. Koefisien format $=0,192$. Artinya jika variabel format mengalami kenaikan sebesar 1 satuan sedangkan variabel lain dianggap konstan, maka variabel dependen yaitu Kepuasan pengguna akan mengalami kenaikan sebesar 0,192 .

6. Koefisien ease of use $=0,404$. Artinya jika variabel ease of use mengalami kenaikan sebesar 1 satuan sedangkan variabel lain dianggap konstan, maka variabel dependen yaitu Kepuasan pengguna akan mengalami kenaikan sebesar 0,404.

\section{4 Uji Hipotesis Model EUCS}

\subsubsection{Ujit}

Uji t dilakukan untuk menguji tingkat signifikansi pengaruh variabel independen terhadap variabel dependen secara parsial. Tingkat signifikansi yang digunakan sebesar 5\% dan nilai t tabel 1,986. Berdasarkan hasil analisis menggunakan SPSS didapatkan hasil seperti pada Tabel 5 dan 6 yang, hasil pengujian secara parsial adalah sebagai berikut:

1. Berdasarkan hasil uji t (parsial) pada model regresi, diperoleh nilai $\mathrm{t}$ hitung 2,615 >t tabel sebesar 1,986 Artinya dapat disimpulkan bahwa secara parsial variabel content berpengaruh terhadap kepuasan pengguna.

2. Berdasarkan hasil uji t (parsial) pada model regresi, diperoleh nilai t hitung sebesar 1,554 < $\mathrm{t}$ tabel sebesar 1,986 artinya dapat disimpulkan bahwa secara parsial variabel accuracy tidak berpengaruh terhadap kepuasan pengguna.

3. Berdasarkan hasil uji t (parsial) pada model regresi, diperoleh nilai t hitung sebesar $1,132<\mathrm{t}$ tabel sebesar 1,986 artinya dapat disimpulkan bahwa secara parsial variabel timeliness tidak berpengaruh terhadap kepuasan pengguna.

4. Berdasarkan hasil uji t (parsial) pada model regresi, diperoleh nilai t hitung sebesar 2,087 > $t$ tabel sebesar 1,986 artinya dapat disimpulkan bahwa secara parsial variabel format berpengaruh terhadap kepuasan pengguna.

5. Berdasarkan hasil uji t (parsial) pada model regresi, diperoleh nilai t hitung sebesar 4,614 >t tabel sebesar 1,986 artinya dapat disimpulkan bahwa secara parsial variabel Ease of use berpengaruh terhadap kepuasan pengguna.

\subsubsection{Uji F}

Uji $\mathrm{F}$ adalah untuk menunjukkan apakah variabel independen yang dimasukkan dalam model mempunyai pengaruh secara bersama-sama terhadap variabel dependen. Pengujian dilakukan dengan tingkat signifikansi $5 \%$ atau 0,05 . Berdasarkan hasil analisis didapatkan hasil seperti gambar 10 . 


\begin{tabular}{|c|c|c|c|c|c|c|}
\hline \multicolumn{7}{|c|}{ ANOVA $^{a}$} \\
\hline Model & & $\begin{array}{c}\text { Sum of } \\
\text { Squares }\end{array}$ & df & Mean Square & $\mathrm{F}$ & Sig. \\
\hline \multirow[t]{3}{*}{1} & Regression & 160.036 & 5 & 32.007 & 54.979 & $<, 001^{b}$ \\
\hline & Residual & 54.724 & 94 & .582 & & \\
\hline & Total & 214.760 & 99 & & & \\
\hline
\end{tabular}

Gambar 10. Hasil Uji F Metode EUCS

Berdasarkan gambar di atas dapat diperoleh nilai $\mathrm{F}$ hitung sebesar 54,979 > F Tabel sebesar 2,31 dengan taraf signifikansi sebesar 0,001. Ini menunjukkan bahwa taraf signifikansi F hitung lebih kecil dari nilai tingkat signifikansi 0,05. Artinya bahwa variabel content, accuracy, timeliness, format, ease of use secara bersama-sama mempunyai pengaruh signifikan terhadap kepuasan pengguna.

\section{4 Uji Hipotesis Model TAM}

Dasar yang digunakan dalam menguji hipotesis adalah nilai yang terdapat pada output path coefficients. Tabel dibawah ini akan memberikan output estimasi untuk pengujian model struktural.

Tabel 7. Hasil Uji Koefisien Determinasi

\begin{tabular}{|c|c|c|c|c|c|}
\hline & $\begin{array}{c}\text { Original } \\
\text { Sample (O) }\end{array}$ & $\begin{array}{c}\text { Sample } \\
\text { Mean (M) }\end{array}$ & $\begin{array}{c}\text { Standard Deviation } \\
(\text { STDEV) }\end{array}$ & $\begin{array}{c}\text { T Statistics } \\
(\mid \text { O/STDEV })\end{array}$ & P Values \\
\hline PEOU -> PU & 0,548 & 0,547 & 0,083 & 6,632 & 0,000 \\
\hline PEOU -> AT & 0,620 & 0,622 & 0,081 & 7,617 & 0,000 \\
\hline PU -> AT & 0,215 & 0,216 & 0,087 & 2,475 & 0,014 \\
\hline AT -> BI & 0,621 & 0,625 & 0,064 & 9,729 & 0,000 \\
\hline BI -> AU & 0,488 & 0,495 & 0,072 & 6,778 & 0,000 \\
\hline
\end{tabular}


Berdasarkan Hasil dari tabel 7 dapat disimpulkan beberapa hasil analisa berdasarkan hipotesis yang sudah dirancang dari awal penelitian yaitu sebagai berikut:

1. Hasil pengujian menunjukkan nilai koefisien perceived ease of use (PEOU) terhadap perceived usefulness (PU) sebesar 0,548 dan t-statistik yaitu sebesar 6,632. Dari hasil ini dinyatakan t-statistik signifikan dikarenakan >1,986 dengan p-value $<0,05$ sehingga membuktikan bahwa perceived ease of use berpengaruh terhadap perceived usefulnes.

2. Hasil pengujian menunjukkan nilai koefisien perceived ease of use (PEOU) terhadap attitude toward using (AT) sebesar 0,620 dan t-statistik yaitu sebesar 7,617. Dari hasil ini dinyatakan t-statistik signifikan dikarenakan $>1,986$ dengan p-value $<0,05$ sehingga membuktikan bahwa perceived ease of use berpengaruh terhadap attitude toward using.

3. Hasil pengujian menunjukkan nilai koefisien perceived usefulness (PU) terhadap attitude toward using (AT) sebesar 0,215 dan t-statistik yaitu sebesar 2,475. Dari hasil ini dinyatakan t-statistik signifikan dikarenakan $>1,986$ sedangkan p-value $>0,05$ sehingga membuktikan bahwa perceived usefulnes berpengaruh terhadap attitude toward using dikarenakan $\mathrm{p}$ value $>0,05$ yaitu sebesar 0,014 .

4. Hasil pengujian menunjukkan nilai koefisien attitude toward using (AT) terhadap behavioral intention (BI) sebesar 0,621 dan t-statistik yaitu sebesar 9,729. Dari hasil ini dinyatakan tstatistik signifikan dikarenakan $>1,986$ dengan $\mathrm{p}$-value $<0,05$ sehingga membuktikan bahwa attitude toward using berpengaruh terhadap behavioral intention.

5. Hasil pengujian menunjukkan nilai koefisien behavioral intention (BI) terhadap actual usage (AU) sebesar 0,488 dan t-statistik yaitu sebesar 6,778. Dari hasil ini dinyatakan tstatistik signifikan dikarenakan $>1,986$ dengan p-value $<0,05$ sehingga membuktikan bahwa behavioral intention berpengaruh terhadap actual usage.

\section{5 Pembahasan}

Hasil analisis terhadap kedua metode yang digunakan dalam penelitian ini, yaitu metode EUCS dan metode TAM, yaitu:

1. Kepuasan Pengguna Terhadap Traveloka Menggunakan Model EUCS

Dari hasil yang didapatkan melalui uji statistik yang dilakukan dengan menggunakan SPSS dengan melakukan uji hipotesis terhadap uji t terhadap variabel content, accuracy, format, ease of use, timeliness terhadap satisfaction (kepuasan pengguna). Didapatkan hasil yaitu variabel content, format, ease of use berpengaruh terhadap satisfaction (kepuasan pengguna Traveloka).

Hal ini menunjukkan bahwasanya tidak semua hipotesis diterima artinya ada beberapa hal yang terkait variabel format dan timeliness, pengguna tidak puas menggunakan aplikasi Traveloka. Walaupun secara simultan pengguna cukup puas.

2. Kepuasan Pengguna Terhadap Traveloka Menggunakan Model TAM

Dari hasil yang didapatkan melalui Path Coefficiencts yang dilakukan dengan menggunakan SmartPLS dengan melakukan uji hipotesis terhadap variabel Attitude Toward Using, perceived ease of use, perceived usefulness, behavioral intention, actual usage. Didapatkan hasil bahwa perceived ease of use berpengaruh terhadap perceived usefulnes, perceived ease of use berpengaruh terhadap attitude toward using, perceived usefulnes berpengaruh terhadap attitude toward using, attitude toward using berpengaruh terhadap behavioral intention dan behavioral intention berpengaruh terhadap actual usage.

Hal ini menunjukkan bahwasanya semua hipotesis diterima artinya pengguna puas menggunakan aplikasi Traveloka.

Dari hasil keseluruhan pengujian hipotesis kepuasan pengguna terhadap Traveloka sebanyak 10 pengujian, diperoleh sebanyak 8 hipotesis yang diterima artinya $80 \%$ disimpulkan bahwa Traveloka memenuhi kepuasan pengguna dan sisanya $20 \%$ pihak pengelola harus memperhatikan faktor tampilan dan respon time aplikasi. 


\section{KESIMPULAN DAN SARAN}

Berdasarkan hasil analisis data yang sudah dilakukan, dapat disimpulkan bahwa dari 10 hipotesis yang diajukan ada beberapa hipotesis yang diterima dan ada yang ditolak. Sesuai dengan rumusan permasalahan yang telah diuraikan di awal terjawab bahwa hasil dari analisis secara parsial dengan menggunakan metode EUCS menunjukan variabel Content (X1) diperoleh nilai t hitung 2,615, variabel Format (X3) diperoleh nilai t hitung sebesar 2,087, variabel Ease of Use (X4) diperoleh nilai t hitung sebesar 4,614 dari hasil tersebut dapat disimpulkan bahwa variabel Content (X1), variabel Format (X3), variabel Ease of Use (X4) berpengaruh terhadap kepuasan pengguna aplikasi Traveloka (Y) sedangkan dengan menggunakan metode TAM semua hipotesis diterima atau berpengaruh terhadap kepuasan pengguna. Hal ini ditunjukkan dengan nilai t-statistik perceived ease of use terhadap perceived usefulness sebesar 6,632, nilai $\mathrm{t}$-statistik perceived ease of use terhadap attitude toward using yaitu sebesar 7,617, nilai tstatistik perceived usefulness terhadap attitude toward using yaitu sebesar 2,475, nilai t-statistik attitude toward using terhadap behavioral intention sebesar 9,729 dan nilai t-statistik behavioral intention terhadap actual usage using sebesar 6,778, sehingga bisa disimpulkan bahwa 5 hipotesis tersebut memiliki pengaruh terhadap kepuasan pengguna aplikasi Traveloka.

Adapun saran yang dapat diberikan untuk penelitian selanjutnya adalah diharapkan untuk penelitian selanjutnya dapat menggunakan metode yang berbeda agar bisa dibandingkan dengan penelitian yang sudah dilakukan sebelumnya, atau dapat menggunakan metode yang sama namun dengan jumlah populasi yang lebih banyak, sehingga bisa lebih mewakili populasi.

Adapun saran yang dapat diberikan untuk perusahaan adalah perusahaan dapat mengoptimalkan dan meningkatkan aplikasi Traveloka untuk dapat memberikan pelayanan yang mengutamakan kepuasan pengguna dan mempertahankan kepercayaan pengguna untuk dapat terus mempertahankan pemanfaatan Traveloka.

\section{DAFTAR PUSTAKA}

[1] K. C. Laudon, C.G. 2014, Traver, E-Commerce 2014, 10th Edition, Pearson.

[2] D. Novita, D. Oktaviany, 2016, "Analisis Penerimaan Layanan Web Tracking Dengan Penerapan Technology Acceptance Model (TAM)”, Jurnal Teknik Informatika dan Sistem Informasi, Vol. 3, No. 01, Hal. 46-60, September 2016, DOI: https://doi.org/10.35957/jatisi.v3i1.64.

[3] Alvara Strategic Research, http://alvara-strategic.com, Diakses Tanggal 20 Desember 2020.

[4] A. Harmadi, B. Hermana, 2005, "Analisis Karakteristik Individu dan Prilaku Pengguna Internet Banking: Reliabilitas dan Validitas Instrumen Pengukuran", Seminar Nasional Aplikasi Teknologi Informasi (SNATI).

[5] A. Mulyani, D. Kurniadi. 2015, "Analisis Penerimaan Teknologi Student Information Terminal (S-IT) Dengan Menggunakan Technology Acceptance Model (TAM)”, Jurnal Wawasan Ilmiah, 7, 23-35.

[6] Doll, W.J., and Torkzadeh, G, 1988, "The Measurement of and User Computing Satisfaction”, MIS Quarterly, Vol. 12, No. 2, hlm. 159-174.

[7] E. Danial, N. Wasriah, 2009, “Metode Penulisan Karya Ilmiah”, Bandung: Laboraterium Pendidikan Kewarganegaraan. 
[8] Sugiyono, 2009, “Metode Penelitian Kuantitatif, Kualitatif dan R\&D”, Bandung: Alfabeta,

[9] D. Novita, D. S. Ningsih, 2020, "Analisis Pengaruh Implementasi E-Learning Vilep di Poltekkes Kemenkes Palembang Dengan Pendekatan EUCS", Jurnal Teknik Informatika dan Sistem Informasi, Vol. 7, No. 01, Hal. 29-41, April 2020, https://doi.org/10.35957/jatisi.v7i1.290.

[10] F. S. Chandra, D. Novita, 2020, "Analisis Penerimaan Masyarakat Terhadap Layanan Transportasi Online Menggunakan UTAUT (Unified Theory of Acceptance and Use of Technology)”, Jurnal Teknologi Sistem Informasi, Vol. 1, No. 1, Hal. 23-33, April 2020.

[11] A. Suharsimi. 2013, "Prosedur Penelitian: Suatu Pendekatan Praktik", Rineka Cipta, Jakarta.

[12] A. A. Hanggono, S. R. Handayani, dan H. Susilo, 2015, "Analisis Atas Praktek Tam (Technology Acceptance Model) Dalam Mendukung Bisnis Online Dengan Memanfaatkan Jejaring Sosial Instagram”, Jurnal Administrasi Bisnis (JAB), Vol. 26, No. 1, September 2015.

[13] Fatmasari, M. Ariandi, 2014, "Penerapan Metode Technology Acceptance Model (TAM) Terhadap Penerimaan Krs Online (Studi Kasus: Mahasiswa Ilmu Komputer Universitas Bina Darma Palembang)", Jurnal Imiah MATRIK, Vol.16, No. 2, 1-20, Agustus 2014.

[14] E. Fatmawati, 2015, "Technology Acceptance Model (TAM) Untuk Menganalisis Penerimaan Terhadap Sistem Informasi Perpustakaan", Jurnal Iqra', Vol. 9 No. 01, Mei 2015.

[15] D. P. S. Ari, 2013, "Pengaruh Technology Acceptance Model dan Pengembangannya Dalam Perilaku Menggunakan Core Banking System”, Jurnal Keuangan dan Perbankan, Vol.17, No.2, hlm. 267-278, Mei 2013.

[16] S. Kurniawati, 2017, "Analisis Pengaruh Perceived Compatibility, Individual Mobility dan Driver's Factor dari Attitude to Wards Use Serta Implikasinya pada Intention to Use: Telaah pada Calon Pengguna Aplikasi Onesmile di BSD City”, Ultima Management: Jurnal Ilmu Manajemen, 9(1), 55-67, DOI: https://doi.org/10.31937/manajemen.v9i1.597.

[17] F. S. Rahayu, D. Budiyanto, and D. Palyama, 2017, "Analisis Penerimaan E-Learning Menggunakan Technology Acceptance Model (Tam) (Studi Kasus: Universitas Atma Jaya Yogyakarta)”, JUTEI, Vol. 1, No. 2, pp. 87-98, Nov 2017.

[18] A. Fitriansyah and I. Harris, 2018, "Pengukuran Kepuasan Pengguna Situs Web Dengan Metode and User Computing Satisfaction (EUCS)," Query J. Sist. Inf., Vol. 2, No. 1, pp. $1-8$.

[19] M. B. Suryawan and P. Prihandoko, 2018, "Evaluasi Penerapan SIAKAD Politeknik Negeri Madiun Menggunakan Pendekatan TAM dan EUCS," Creat. Inf. Technol. J., Vol. 4, No. 3, p. 233, doi: 10.24076/citec.2017v4i3.113.

[20] A. Saputra and D. Kurniadi, 2019, "Analisis Kepuasan Pengguna Sistem Informasi ECampus Di Iain Bukittinggi Menggunakan Metode Eucs," J. Vokasional Tek. Elektron. dan Inform., vol. 7, no. 3, pp. 58-66. 
[21] Meyliana, H. Antonius E.W, S. W. Santoso, , 2012, "Kepuasan Mahasiswa terhadap Implementasi E-CRM pada Binus University", Jurnal ComTech: Computer, Mathematics and Engineering Applications, Vol. 3, No. 1, DOI: https://doi.org/10.21512/comtech.v3i1.2422. 